\title{
Georg Kirstenius (1613-1660) i Johann Zander (1624-1695) - profesorowie medycyny w szczecińskim Pedagogium Książęcym / Gimnazjum Karolińskim wobec jatrochemii
}

Słowa kluczowe: XVII-wieczna chymia; jatrochemia; aurum potabile

Fakt istnienia w XVII-wiecznym Szczecinie szkoły z katedrą medycyny jest mniej powszechnie znany niż to, że podobna instytucja działała w XVII- i XVIII-wiecznym Gdańsku. Nic w tym dziwnego: podczas gdy gdańska profesura medycyny jest od dłuższego czasu integralną częścią systematycznych badań nad historią tamtejszego Gimnazjum Akademickiego ${ }^{52}$, dzieje szczecińskiego Gimnazjum Mariackiego $^{53}$ dopiero od niedawna stanowią przedmiot poważnego

${ }^{51}$ Zakład Historii Medycyny i Etyki Lekarskiej, Pomorski Uniwersytet Medyczny, Szczecin, e-mail: joanna.nieznanowska@pum.edu.pl, ORCID: 0000-0002-4631-4510.

52 Por. m.in. A. Szarszewski, Medycyna i jej więzi z gdańskim Gimnazjum Akademickim, [w:] Gdańskie Gimnazjum Akademickie. T. 5. Źródła i artykuły, L. Mokrzecki, M. Brodnicki (red.), Gdańsk 2012, s. 81-90; Joachim Oelhaf i jego następcy, A. Szarszewski, B. Siek (red.), Gdańsk 2013; Uczniowie Hipokratesa nad Mołtawa, A. Szarszewski, M. Otto (red.), Gdańsk 2017.

${ }^{53}$ Szkoła przy kolegiacie Najświętszej Marii Panny w Szczecinie wielokrotnie zmieniała nazwy (1544-1667: Pedagogium Książęce; 1668-1715: Królewskie Gimnazjum 
zainteresowania polskich historyków ${ }^{54}$, a w pracach już opublikowanych brakuje informacji dotyczących medycyny ${ }^{55}$ (w niemieckich opracowaniach historii szczecińskiej szkoły też było ich bardzo niewiele $\left.{ }^{56}\right)$. Celem niniejszej pracy jest przedstawienie stosunku pierwszych szczecińskich profesorów medycyny do chymii ${ }^{57}$ i jatrochemii kwestii tej dotychczas nie analizowano. Zanim jednak przejdziemy do rzeczy, przedstawmy pokrótce okoliczności, w jakich zainaugurowano nauczanie medycyny w Szczecinie.

Okres największego rozkwitu w 400-letniej historii Gimnazjum Mariackiego przypadł na czas najmniej, wydawałoby się, sprzyjający. Po bezpotomnej śmierci Bogusława XIV (1637) Księstwo Pomorskie przestało istnieć, a jego terytorium podzielono między Brandenburgię

Karolińskie; 1716-1805: Królewskie Gimnazjum Akademickie; 1805-1869: Królewskie i Miejskie Gimnazjum; po 1869: Gimnazjum Fundacji Mariackiej). W pracy używam potocznej nazwy szkoły (Gimnazjum Mariackie).

${ }^{54} \mathrm{~W}$ styczniu 2016 r. i grudniu 2017 r., pod auspicjami i z inicjatywy Książnicy Pomorskiej, odbyły się ogólnopolskie konferencje poświęcone historii szkoły. Kwestie związane z kształceniem medycznym prowadzonym w szczecińskim Gimnazjum były prezentowane na obu spotkaniach. Cykl konferencji ma być kontynuowany, a jego owocem będzie seria monografii eksplorujących działalność i znaczenie placówki oraz związanych z nią osób i instytucji. Właśnie ukazał się tom inicjujący serię: Od Pedagogium Ksiażęcego do Gimnazjum Mariackiego. Z dziejów szkolnictwa pótwyższego w Szczecinie do początków XIX w., A. Borysowska (red.), Szczecin 2018. Dwa rozdziały poświęcone interesującemu nas okresowi w dziejach Gimnazjum Mariackiego zawarto w monografii upamiętniającej 70-lecie szkolnictwa wyższego na polskim Pomorzu Zachodnim. R. Gaziński, Pedagogium Ksiażęce (lata 1544-1667), [w:] Akademicki Szczecin, XVI-XXI wiek, Szczecin 2016, s. 15-46; P. Gut, Szczecińskie akademickie szkoły średnie w II połowie XVII i XVIII wieku. Gimnazjum Karolińskie (lata 1667-1716), w: Akademicki Szczecin..., dz. cyt., s. 47-80.

${ }^{55}$ Najważniejszymi polskimi opracowaniami tematu pozostają: S. Schwann, Poczatki nauczania medycyny w Szczecinie, „Archiwum historii medycyny” 1964, s. 373-378; E. Dorsz-Szteke, Nauczanie medycyny na Pomorzu Zachodnim w I pot. XVIII wieku, „Archiwum historii medycyny” 1980 s. 305-310. Działalność pierwszych szczecińskich profesorów medycyny jest też wzmiankowana we wspomnianym wyżej Akademickim Szczecinie..., dz. cyt., s. 33 (jednozdaniowa informacja o rozszerzeniu programu nauczania o medycynę w XVII w.); P. Gut, dz. cyt., s. 54-57 (ogród botaniczny), 61 (założenia programowe nauczania medycyny).

${ }^{56} \mathrm{Z}$ niemieckich opracowań najobszerniejsze informacje na ten temat przedstawił Martin Wehrmann, w którego monografii poświęconej historii szczecińskiego Gimnazjum kwestie związane z nauczaniem medycyny zajęły w sumie 3 ze 165 stron tekstu. M. Wehrmann, Geschichte der Kōniglichen Marienstifts-Gymnasiums (des früheren herzoglichen Pädagogiums und kōnigl. akademischen Gymnasiums) in Stettin 1544-1894, Stettin 1894 (pojedyncze wzmianki dotyczące nauczania medycyny w Gimnazjum: s. 60, $68,79,80,89,91,96,114,122,123,142,146)$.

57 Używam tego terminu za L. Principem i W.R. Newmanem i zgodnie z ich definicją („,wczesnonowożytna alchemia-chemia”). W.R. Newman, A Note on Terminology, [w:] tegoż, Atoms and Alchemy: Chymistry and the Experimental Origins of the Scientific Revolution, Chicago, London 2006, s. xi. 
i Szwecję (pokój westfalski, 1648; traktat szczeciński, 1653). Szczecin i Greifswald oraz mieszczące się w nich Pedagogium i Uniwersytet przypadły Koronie Szwedzkiej, już od 1630 r. sprawującej faktyczny zarząd nad Pomorzem ${ }^{58}$. Uniwersytet $\mathrm{w}$ Greifswaldzie (założony w 1456 r.) włączono do szybko rosnącej szwedzkiej sieci akademickiej, składającej się z uczelni w Uppsali (1477; wydział lekarski faktycznie działający od 1615 r.), Dorpacie (dziś: Tartu w Estonii; 1632) i Åbo (dziś: Turku w Finlandii; 1640). Rektor szczecińskiego Pedagogium Johannes Micraelius ${ }^{59}$ miał ambicje przekształcić kierowaną przez siebie szkołę w czterowydziałowy uniwersytet. Nie tylko doprowadził do otwarcia w Szczecinie profesury prawa (1642) i medycyny (1647), ale także zebrał wokół siebie grono znakomitych wykładowców, dzięki czemu w latach 40. i 50. XVII stulecia Pedagogium było de facto (choć nie de iure) akademią ${ }^{60}$. Uniwersyteckie ambicje Micraeliusa podzielał pierwszy szczeciński profesor medycyny Georg Kirstenius, który prowadził wykłady i demonstracje zgodnie z curriculum praktykowanym w najlepszych północnoeuropejskich wydziałach lekarskich ${ }^{61}$. Po śmierci Micraeliusa (1658) i Kirsteniusa (1660) Pedagogium upadło. W 1667 r. szkoła została rozwiązana, a w jej miejsce władze szwedzkie powołały do życia Królewskie Gimnazjum Karolińskie. Utrzymano w nim katedrę medycyny, którą objął Johann Zander ${ }^{62}$.

Zarówno w przypadku Kirsteniusa, jak i Zandera brakuje nam wielu informacji biograficznych. O życiorysie pierwszego wiemy co prawda sporo ${ }^{63}$, za to dokumenty związane z jego pracą $\mathrm{w}$ Szczecinie zaginęły jeszcze przed końcem XVII w.; co do Zandera, dysponujemy pewnym zasobem archiwaliów dotyczących jego profesury ${ }^{64}$, ale tyl-

${ }_{58}$ B. Wachowiak, Upadek państwa zachodniopomorskiego, [w:] Historia Pomorza, G. Labudy (red.), t. II, cz. I, s. 997-1012; Z. Szultka, Pokój westfalski i podział Pomorza Zachodniego między Szwecję i Brandenburgię, [w:] Historia Pomorza, G. Labudy (red.), t. II, cz. III, s. 234-238.

${ }_{59}$ G. v. Bülow, Micraelius, Johann, „Allgemeine Deutsche Biographie“, Muenchen 1885, Bd. 21, s. 700-701.

${ }_{60}$ M. Wehrmann, dz. cyt., s. 49-73.

${ }^{61} \mathrm{~J}$. Nieznanowska, Syzyfowe prace. 175 lat starań profesorów medycyny Pedagogium Książęcego / Gimnazjum Karolińskiego / Królewskiego Gimnazjum Akademickiego o powstanie w Szczecinie uniwersyteckiego wydziału lekarskiego, [w:] Od Pedagogium Ksiażęcego do Gimnazjum Mariackiego..., dz. cyt., s. 73-90, tu: s. 76-80.

${ }^{62} \mathrm{M}$. Wehrmann, dz. cyt., s. 75-77, 79.

${ }^{63} \mathrm{H}$. Schaevius, Monumentum literarum Viro Nobili [...] DN Georgio Kirstenio [...] Paedagogii Regii Prof. \& Pract. apud Stetinenses famigerabili [...], [w:] Memoriae medicorum nostri saeculi clarissimorum renovatae. Decas secunda, H. Witte (red.), Francofurti 1676, s. 209-214.

${ }^{64}$ Archiwum Państwowe w Szczecinie, Fundacja NMP w Szczecinie sygn. 880; sygn. 1494, s. 1-5. 
ko szczątkową wiedzą o jego aktywności zawodowej i naukowej przed objęciem stanowiska w Gimnazjum ${ }^{65}$. W każdym razie i Kirstenius, i Zander urodzili się w Szczecinie, obaj też byli uczniami Pedagogium. Kirstenius studiował medycynę w Jenie i Strasburgu oraz na uniwersytetach niderlandzkich, przede wszystkim w Lejdzie, gdzie w 1638 r. obronił doktorat ${ }^{66}$. Zander studia medyczne odbył we Frankfurcie nad Odrą, w Helmstedt i Rostocku; on również obronił doktorat w Lejdzie $(1649)^{67}$. Kirstenius po studiach mieszkał i praktykował w Holandii, najprawdopodobniej w Amsterdamie, skąd w 1646 r., na prośbę Micraeliusa, wrócił do Szczecina. Zanim Zander został w 1667 r. powołany na stanowisko lekarza krajowego szwedzkiego Pomorza, miał pracować w Gdańsku i Królewcu. Nie znamy warunków, na jakich profesurę medycyny przyznano Kirsteniusowi, wydaje się jednak, że były one bardzo korzystne: miał cztery godziny wykładów w tygodniu (jego następcy - dwie) oraz wolną rękę w doborze tematyki i formy prowadzonych zajęć, a jego wynagrodzenie mogło dorównywać rektorskie$\mathrm{mu}^{68}$. $\mathrm{Z}$ kolei obowiązki profesorskie Zandera zostały jasno określone w regulaminie Królewskiego Gimnazjum Karolińskiego: profesorem medycyny stawał się automatycznie lekarz krajowy; w szkole miał on przede wszystkim opiekować się chorymi studentami i zajmować się „promocją zdrowia”. W ramach tejże, poza organizowaniem studentom zajęć ruchowych i pilnowaniem, by dostatecznie dbali oni o higienę osobistą, profesor miał prowadzić demonstracje anatomiczne na zwłokach ludzkich i zajęcia z botaniki lekarskiej ${ }^{69}$. Za pracę w Gimnazjum lekarz krajowy nie otrzymywał odrębnego wynagrodzenia pieniężnego - przez ponad 100 lat kolejnym profesorom medycyny nie udało się wywalczyć zmiany tego przepisu.

W trakcie profesury w Szczecinie i Kirstenius, i Zander zabrali głos w debacie toczącej się wówczas wokół chymii i jatrochemii oraz war-

${ }^{65}$ Stosunkowo najobszerniejsze informacje biograficzne o Zanderze zamykają się w dziesięciowersowym haśle leksykonu Vanselowa. A.C. Vanselow, Gelehrtes Pommern oder alphabetische Verzeichniß einiger in Pommern gebohrnen Gelehrten [...], Stargard 1728, s. 131.

${ }^{66}$ G. Kirstenius, Disputatio medico-philosophica inauguralis De lumbricis [...], Lugduni Batavorum, [1638].

67 J. Zander, Disputatio inauguralis medica De palpitatione cordis [...], Lugduni Batavorum 1649.

${ }^{68} \mathrm{O}$ wymiarze czasowym i tematach wykładów Kirsteniusa mówią katalogi zajęć publicznych Pedagogium (Elenchi Operarum Publicarum) z lat 1648-1658. O tym, że Kirstenius otrzymywał wynagrodzenie w kwocie 200 talarów rocznie, świadczy pokwitowanie wystawione przez niego w maju 1648 r., dziś w zbiorach Biblioteki Uniwersyteckiej w Uppsali (sygn. Waller Ms se-01589).

69 Verfassung des Gymnasii Carolini zu Alt. Stettin [...], Stettin 1667, s. 14-15. 
tości medykamentów chymicznych, które od czasów Paracelsusa zyskiwały w Europie rosnącą popularność. Każdy z nich jednak wystąpił $\mathrm{w}$ tym dyskursie $\mathrm{w}$ nieco odmiennej roli i z innych motywacji: Kirstenius jako uczony akademik, Zander - jako urzędnik państwowy.

Wiemy, że krytyka chymii i jatrochemii stanowiła część wykładu medycyny prowadzonego przez Kirsteniusa w Szczecinie. W semestrze zimowym 1649/1650 jeden z jego studentów - Nicolaus Milovius - przedstawił (niewątpliwie napisaną przez profesora) dysputę De natura rerum naturalium et in specio de Elementis ac Principiis Chymi$c i s^{70}$. Jej tekst nie zachował się, więc nie może nam posłużyć za źródło wiedzy o poglądach Kirsteniusa na chymię. Za to ze sposobu, w jaki zapowiedział on tematykę wykładów na semestr zimowy 1650/1651, jasno wynika, jakie było jego stanowisko wobec paracelsjańskiej filozofii przyrody: zamierzał naświetlić „obrzydliwe błazeństwa Helmontiańskie, oraz Paracelsusa niby-greckie Iliastrici, Cagastrici, Pagoici, Evestrici, Nostochici, Scajolici i tym podobne głupstwa" ${ }^{11}$. Znacznie szerzej swoją ocenę jatrochemii przedstawił Kirstenius w wydanych w 1648 r. „,sprzeciwach i krytykach"72 do dwóch dzieł autorstwa wrocławskiego lekarza Johanna Agricoli: jego alchemiczno-lekarskich komentarzy do Medycyny chymicznej Johanna Poppiusa ${ }^{73}$ oraz podręcznika Chirurgia parva ${ }^{74}$.

Rozprawa Kirsteniusa z Agricolą składa się z dwóch części. Pierwsza, zatytułowana Medicaster, sive De erroribus et ineptiis medientium dissertatio praeliminaris, to 42-stronicowa, napisana po łacinie filipika na „uzurpatorów” i „konowałów” którzy, nie posiadając wiedzy i kwalifikacji niezbędnych do leczenia ludzi, używają chymii jako wygodnej furtki dającej im dostęp do chorych, zawsze gotowych płacić za pięknie i tajemniczo ponazywane, rzekomo cudowne kuracje. Zdaniem Kirsteniusa wymyślne chymiczne nazwy chorób (,a to stomacacen, a to sceletyrben”) i leków to pustosłowie. Szczeciński profesor cytuje kilka receptur na mikstury i konkokcje zachwalane przez tych „Artis spagyricae Amatores, aut Cultores”; napisane w mieszaninie skażonej łaciny i pospolitej niemczyzny, i rojące się od absurdalnych

${ }^{70}$ Exercitationum Publicarum in Illiustri Paedagogio Stetinensi [...] elapse semestri hiberno anni $1649 \& 50$ adornatarum Designatio.

${ }^{71}$ Elenchus Operarum Publicarum [...], Anno [...] 1650 \& 51 Per semestre spatium hibernum [...].

${ }^{72}$ G. Kirstenius, Adversaria, et Animadversiones, in Johannis Agricolae [...] Commentaria in Poppium, \& Chirurgiam parvam [...], Alten Stettin 1648.

${ }^{73} \mathrm{~J}$. Agricola, Commentariorum, Notarum, Observationum \& Animadversionum in Johannis Poppii Chymische Medicin [...] erste / andere Theil, Leipzig 1638/1639.

${ }^{74}$ J. Agricola, Chirurgia parva [...], Nürnberg 1646. 
błędów, musiały na nim wywierać wrażenie podobne do tego, jakie na dzisiejszym czytelniku Imienia róży Umberta Eco sprawia wielojęzyczny bełkot Salvatora.

Druga część to liczące 600 stron właściwe Adversaria et Animadversiones, napisane po niemiecku z licznymi dygresjami łacińskimi. Tę narrację Kirstenius podzielił na pięć sekcji. W pierwszej (s. 1-100) kreśli historię objawiania się w europejskiej medycynie różnorakich sekt medycznych (od zwalczanych przez Galena metodyków, po zwolenników Paracelsusa), rozprawia się z poglądem entuzjastów terapii chymicznych (,empiryków”), że spójna podbudowa teoretyczna metody leczniczej nie jest konieczna, gdy doświadczenie przemawia za skutecznością takiego czy innego postępowania, przede wszystkim jednak przeprowadza gruntowną krytykę opisanych przez Agricolę przypadków skutecznego działania „złota pitnego” i innych specyfików proweniencji alchemicznej; kończy próbą wyjaśnienia, dlaczego kuracje ze złotem w nazwie cieszą się tak wielką popularnością. W drugiej sekcji (s. 101-208) Kirstenius drobiazgowo analizuje przedstawione w Komentarzach do Poppia relacje Agricoli z jego podróży naukowych, liczne kazusy, gdy przepisane przez niego kuracje miały cudownie leczyć choroby, wobec których inni lekarze byli bezradni, a także zdumiewające alchemiczne eksperymenty, których Agricola miał być naocznym świadkiem. W trzeciej i czwartej sekcji egzaminowi podlega „methodus medendi Agricolaea” z Komentarzy do Poppia (s. 208-276) i Chirurgii małej (s. 276-530). Ostatnią sekcję (s. 530-594) Kirstenius przeznacza na krytykę ,pewnych kwestii egzoterycznych, przyrodniczych, medycznych, teologicznych i filologicznych", które go w publikacjach Agricoli szczególnie zirytowały.

Uderza, że Kirstenius w ogóle nie zajmuje się kwestią rzeczywistego składu opisywanych przez Agricolę leków chymicznych czy sposobu ich otrzymywania. Gdy pisze on (w samych pejoratywach) o wartości terapeutycznej ,pitnego złota”, nie zastanawia go, czy preparat zachwalany przez adwersarza zawiera złoto. Źródłem niezgody Kirsteniusa jest przede wszystkim to, że Agricola przedstawia swoje chymiczne terapie jako jedyny skuteczny sposób postępowania, wobec którego leki galenowe (roślinne) i dieta mogą pełnić tylko funkcję uzupełniającą - o ile w ogóle są przydatne. Rozprawiając się z tezami przedstawionymi w pismach wrocławskiego jatrochemika, Kirstenius stosuje kilka strategii. Po pierwsze, korzysta z prac uczonych, którzy, osobiście zaangażowani w intensywne badania nad chymią, podejmowali próby pogodzenia idei paracelsjańskich i jatrochemii z porząd- 
kiem arystoteliańskim i medycyną galenową - albo znajdując punkty styczne tych systemów, albo wykazując wyższość arystotelizmu. Szczególnie często i precyzyjnie powołuje się na Thessalusa $w$ chymikach odrodzonego Antona Günthera Billicha ${ }^{75}$, Komentarz o prawdziwym pożytku $i$ nieprzystojnym nadużywaniu medykamentów chymicznych Laurentiusa Hofmanna ${ }^{76}$, przede wszystkim jednak na Księge o zgodzie i niezgodzie chymików z arystotelikami i galenikami oraz Paralipomena Daniela Sennerta ${ }^{77}$. W pracach tych Kirstenius znajduje $\mathrm{z}$ jednej strony argumenty na obronę medycyny hipokratejskiej i galenowej, z drugiej zaś przykłady na rozmijanie się poglądów wrocławskiego lekarza z tezami czołowych reprezentantów chymii. Tak właśnie wykorzystuje przedstawioną w „Paralipomena” Sennerta dyskusję nad sednem różnicy między octem winnym i winem: na jej kanwie, i łącząc sposób, w jaki pojęciem „redukcji do materii pierwszej” posługiwali się Sennert i Arystoteles, Kirstenius argumentuje, że rozmaite zabiegi stosowane przez chymików, by wzmocnić lub poprawić właściwości lecznicze złota, są bezcelowe. Jak bowiem w przypadku przekształcania owoców winorośli w ocet lub wino dochodzi do separacji pewnych odrębnych właściwości obecnych w winnych gronach (dzięki czemu $\mathrm{z}$ tego samego substratu można otrzymać różne produkty końcowe), tak „złoto pozostaje niezmienne. [...] Przy każdej alteracji ciała zachodzi redukcja do materii pierwszej; w żadnym roztworze złota (z wyjątkiem menstruo universali) nie zachodzi taka redukcja. Ergo, w żadnym roztworze złota nie dochodzi do alteracji" Tym samym zachwalanie „złota pitnego” jako medykamentu lepszego od surowego złota jest pozbawione sensu. Równie absurdalne jest dla Kirsteniusa, że sami chymicy nie mogą dojść do porozumienia z czego właściwie biorą się niezwykłe właściwości, którymi ma się wyróżniać „aurum potabile”. Kirstenius, powołując się na szereg ustępów z Komentarzy Agricoli, zauważa złośliwie, że elementu mającego odpowiadać za te szczególne zalety:

75 A.G. Billich, Thessalus in chymicis redivivus, id est, de vanitate medicinae chymicae, hermeticae, seu spagyricae [...], Francofurti ad Moenum 1640. Kirstenius odwoływał się również do Anatomia fermentationis Platonicae apodictica et paradocologa tegoż autora.

${ }^{76}$ L. Hofmann, De vero usu et fero abusu medicamentorum chymicorum commentatio, Halae Saxonum 1611.

${ }_{77}$ D. Sennert, De chymicorum cum Aristotelicis et Galenicis consensu ac dissensu liber, Wittembergae 1619; tegoż, Paralipomena, cum praemissa methodo discendi medicina [...], Wittembergae 1642.

${ }^{78}$ G. Kirstenius, Adversaria [...], s. 82-83. 
szuka się już to $\mathrm{w}$ witriolu (de vitriolo, s. 373), już to $\mathrm{w}$ antymonie (de antimono, s. 226), to znów porzuca się zupełnie złoto (de antimono, s. 227), a skoro [element ten] ma być niezniszczalny, trzeba go szukać w jakimś innym ciele; lecz przecież jest kwestią wątpliwą, czy choćby sam Mercurius Philosophorum, prawdziwe i jedyne menstruum mundi universale, mógłby nim być. Tegoż szukają oni wszyscy, i nigdzie nie mogą znaleźć [...] pośród ich dziesięciu tysięcy ani jednego, który by wiedział, czego szuka (de sale, s. 775); sam Agricola pewnie tego nie wie. Bo raz jest to Smok, a raz Zielony Lew; raz Szary, a raz Biały Wilk; a jeszcze kiedy indziej będzie to woda $z$ Indii, praesertim Wschodnich (de sale, s. 797), która chłodzi i ogrzewa, wysusza i nawilża, jest i nie jest $[\ldots]^{79}$.

Po drugie, Kirstenius skrupulatnie odnotowuje każdy nieścisły lub nieprawdopodobny element narracji autobiograficznej Agricoli. Sporządza w tym celu dwa rejestry. Pierwszy to Index chronologicus et corographicus (s. 114-121), w którym, jak na osi czasu z mediów społecznościowych, zostają wyliczone miejscowości, do których Agricola miał podróżować, w których miał mieszkać, pobierać nauki i praktykować (medycynę i chymię), oraz zawierać znajomości, którymi się chwalił - z precyzyjnymi odwołaniami do odpowiednich ustępów w Komentarzach i Chirurgii. Drugi to wykaz kuracji wzmiankowanych w Komentarzach jako dokonane osobiście przez Agricolę, z podziałem na zastosowane medykamenty chymiczne (s. 206-208). Z indeksu wynika, że Agricola już jako 17-latek miał własną praktykę, nie miał za to zbyt wiele czasu i okazji, by odbyć rzetelne studia ${ }^{80}$. Wykaz kuracji dowodzi zaś, że wrocławski lekarz przypisał sobie leczenie (w ciągu nie więcej niż 37 lat) ponad 128 tys. osób. Tak ogromna przesada, zdaniem Kirsteniusa, jednoznacznie dyskredytuje wiarygodność autora Komentarzy i wszystkich głoszonych przezeń twierdzeń.

Równie skrupulatnie (i złośliwie) szczeciński profesor przywołuje i komentuje opisane przez Agricolę alchemiczne i magiczne eksperymenty i przygody, których ten miał być naocznym świadkiem lub uczestnikiem, a które zdaniem Kirsteniusa albo w ogóle nie miały miejsca, albo były oszustwem, na którym jego adwersarz się nie poznał. Dziwi się więc, jak często Agricoli zdarzało się odnajdować po klasztorach (,a to w Austrii, a to w Chorwacji”) starożytne rękopisy

${ }^{79}$ Tamże, s. 89-90.

${ }^{80}$ Kirstenius nie wiedział, że Agricola, pisząc Komentarze, odmłodził się o kilka lat. 
skrywające potężne tajemnice alchemiczne ${ }^{81}$; $\mathrm{z}$ rozbawieniem odnosi się do „naocznych” relacji z zabiegów transmutacji metali nieszlachetnych w złoto 82 ; naigrywa się z opisu „resuscytacji rośliny”, której Agricola miał być świadkiem u pewnego wiedeńskiego aptekarza, zdolnego uschniętą gałązkę kasztanowca przerobić „na piękną krystaliczną sól” (którą „włożył do ziemi i obficie podlewał, i wyrosła roślina, zupełnie jak tamta gałązka") ${ }^{83}$; druzgoczącej krytyce poddaje też chymiczne oraz magiczne teorie i kuracje opisane przez Agricolę w Chirurgia parva (szczególnie bezlitośnie rozprawia się z zachwalaną tam „maścią wojenną”, unguentum armarium, mającą wywoływać efekt leczniczy drogą magii sympatycznej, przez aplikację nie na ranę, lecz na narzędzie, którym ta została zadana) ${ }^{84}$.

Ostatni rozdział „Sprzeciwów i krytyk” to analiza biegłości Agricoli w posługiwaniu się łaciną i greką ${ }^{85}$. Kirstenius interesował się językoznawstwem od czasu studiów w Lejdzie, gdzie jednym $\mathrm{z}$ jego nauczycieli był Cornelis Schrevel, autor wielokrotnie wznawianego słownika grecko-łacińskiego i wydawca autorów klasycznych. Poza niemieckim, łaciną i greką Kirstenius znał języki hebrajski, arabski, włoski i (zapewne) niderlandzki. Fascynacje językoznawcze natchnęły go do własnych, oryginalnych badań, w których łączył elementy filologii, filozofii, teologii i botaniki; ich efektem były dwie nowatorskie w charakterze „rozprawki fitofilologiczne” ${ }^{\text {. W }}$. sprawie swej polemiki z Agricolą korespondował z wybitnym językoznawcą, Gerhardem Vossiusem ${ }^{87}$. Kirstenius uważa kwalifikacje językowe Agricoli za wysoce niezadowalające. Niedoskonałości lingwistyczne ocenianych tekstów są dla niego ostatecznym dowodem ich głębokiej wewnętrznej ułomności.

O poglądach Johanna Zandera na chymię i jatrochemię dowiadujemy się z mniej bogatych i pewnych źródeł. Chociaż zachowane ar-

${ }^{81}$ G. Kirstenius, Adversaria [...], s. 121-128.

${ }^{82}$ Tamże, s. 128-139. W innym miejscu (s. 146) Kirstenius przypuszcza, że źródłem opowieści Agricoli o jakoby oglądanej przezeń zamianie ołowiu w złoto przy pomocy „czerwonego proszku” mogła być wzmianka Josepha Duchesne (Quercetanusa), że widział on $u$,pewnego polskiego filozofa” (Sędziwoja?) proszek mający zdolność m.in. transmutować metale w złoto i ożywiać rośliny.

83 Tamże, s. 144-146.

84 Tamże, s. 276-292.

85 Tamże, s. 563-594.

${ }^{86}$ G. Kirstenius, Exeritationum Phyto-Philologicarum ex Sacris Prima, de Dudim et Manna Israelitarum [...], Stetini 1651; tenże, Exercitationum Phyto-Philologicarum ex Sacris Secunda, de Colocynthide Prophetica et Cocco [...], Stetini 1651.

${ }^{87}$ Doctissimi [...] Gerardi Joannis Vossi et ad eum [...] epistolae [...] Iterata Editio, P. Colomesius (red.), Londini 1693, vol. 2, s. 286-287 (nr CDXXXV, Stetini 5. Maii 1647). 
chiwalia jednoznacznie wskazują, że sumiennie wypełniał on swoje obowiązki dydaktyczne ${ }^{88}$, nie wiemy, czego konkretnie nauczał, bo nie prowadził wykładów publicznych (prawdopodobnie z powodu braku dostatecznej liczby chętnych słuchaczy), a tematyka zajęć typu privata i privatissima nie była przedstawiana w planach dydaktycznych Gimnazjum. Nie zachowały się również jakiekolwiek publikacje na interesujący nas temat, których byłby on jedynym autorem. Musimy więc zdać się na materiał poszlakowy. Wiadomo, że Zander pełnił funkcje lekarza krajowego i, jako taki, przewodniczył miejscowemu Collegium Medicum. W świetle obowiązujących wtedy przepisów aptekarskich to drugie stanowisko wolno było powierzyć tylko „uczonemu medykowi biegłemu w doktrynie Hipokratesa, Galena i Paracelsusa" ${ }^{89}$ - a więc Zander musiał być uważany za eksperta w dziedzinie chymii i jatrochemii. Dalszych przesłanek, że był on praktykującym chymikiem, dostarcza polemika z 1683 r. którą napisał wspólnie z lekarzami wraz z nim tworzącymi Collegium Medicum; Zander jest wymieniony jako pierwszy autor tego tekstu (liczącego 54 strony, a więc znacznie mniej obszernego niż omówione wyżej dzieło Kirsteniusa). Ostry sprzeciw Collegium Medicum sprowokowały poczynania Johanna i Gottfrieda Richterów, synów aptekarza z Zittau w Saksonii, którzy na przełomie lat 1681/1682, osiadłszy w Szczecinie, rozpoczęli reklamę i sprzedaż chymicznych „panaceów”. Swoją opinię o rzeczywistej wartości owych preparatów autorzy wyrazili już w barokowo rozbuchanym tytule polemiki: Zmora tajemnic Richtera ujawniona / albo wiarygodne odkrycie / kilku Tajemnic i Medykamentów Alchemicznych Richtera zamaskowanych $i$ utajonych pod olśniewającymi tytułami, rozgłaszanymi także u nas w Starym Szczecinie / jak: Astri $\odot$ purgantis; Tincturae $\odot$ albo Złotej Tynktury, Tincturae Anti-Tartareae albo Uniwersalnej Tynktury na Kamień, Panaceae albae fixae etc.; $\dot{z}$, poddane starannym badaniom, okazały się one tak złej próby / $i$, wbrew buńczucznym i niemal szalbierskim zapewnieniom / zupetnie nie nadaja sie do używania we wszystkich chorobach cielesnych bez różnicy $[\ldots]^{90}$. Publikacja ta zapoczątkowała dłuższą wymianę reto-

${ }^{88}$ Dokumenty dot. działalności profesorskiej: por. przyp. 13.

${ }^{89}$ Von den Medicis, [w:] Reformatio Pharmacopoliorum Stetinensium [...], Alten Stettin 1628.

${ }^{90}$ J. Zander, J.G. Liebe, D.G. Kluge, J. Gerdes, Larva Arcanorum Richteri detecta, oder Warhafftige Entdeckung / Einiger unter hoch-herprangenden Tituln vermummetund verkappeten [...] Secreten und Chimischen Medicamenten / als: Astri $\odot$ purgantis; Tincturae $\odot$ oder Gold-Tinctur, Tincturae Anti-Tartaricae oder Universal Stein-Tinctur, Panaceae albae fixae etc. des Richters; wie dieselbige bey fleißiger Untersuchung so schlechte Proben gehalten / und dahero dem ruhmrähtigen / fast quacksalberigen Für- 
rycznego ognia między Richterami i Collegium. Richterom zarzucono m.in. nielegalną sprzedaż środków przedstawianych jako skuteczne i uniwersalne leki oraz rozpowszechnianie fałszywych informacji o składzie i działaniu owych preparatów, szczególnie zaś sugerowanie, że w ich skład wchodzi złoto i drogie kamienie.

Trzon Zmory stanowią cztery rozdziały poświęcone kolejno wymienionym w tytule specyfikom sprzedawanym przez Richterów. Każdy rozdział rozpoczyna gruntowna krytyka treści, jakie na temat danego preparatu Richterowie zamieścili w rozprowadzanych w Szczecinie ulotkach reklamowych. Punkt po punkcie Zander i współautorzy dowodzą, że najeżone symbolami alchemicznymi, skomplikowane sformułowania używane $w$ tych reklamach są sprzeczne i ze stanem wiedzy medycznej, i z poglądami najwybitniejszych przedstawicieli jatrochemii; tym samym wykazują, że Richterowie są albo zupełnymi ignorantami, albo też cynicznie wykorzystują w ulotkach zawiłe zwroty i tajemnicze symbole, by zaimponować klientom i wzbudzić $\mathrm{w}$ nich wiarę $\mathrm{w}$ potężną moc sprzedawanych za niemałe pieniądze preparatów. Następnie przedstawione zostają wyniki ,prób ognia probierczego", czyli eksperymentów przeprowadzonych przez członków Collegium celem ustalenia rzeczywistego składu środków rozprowadzanych przez Richterów. Tu znajdujemy, zapisane z wykorzystaniem symboli alchemicznych, drobiazgowe opisy zabiegów laboratoryjnych, jakim autorzy Zmory poddali badane substancje, oraz wyniki tych eksperymentów, które dowiodły, że specyfiki Richterów w ogóle nie zawierały złota, a głównie rtęć i antymon. Śledzenie skomplikowanego wywodu ułatwiają zamieszczone na marginesach jednozdaniowe „tytuły” zawierające podsumowanie danego akapitu i wyniki poszczególnych prób. Uderza swoboda, z jaką autorzy posługują się nomenklaturą chymiczną. Zander i jego współpracownicy doskonale rozumieli język, który dla Kirsteniusa był budzącym odrazę bełkotem. Autorzy Zmory, choć świetnie zorientowani w jatrochemii, nie byli jednak jej bezkrytycznymi zwolennikami. Nie zgadzali się ani $\mathrm{z}$ dogmatem Paracelsusa o trzech pryncypiach, ani z jego wykładnią doktryny sygnatur, jednak o obu tych kwestiach pisali ze znawstwem, wyjaśniając czytelnikom właściwe znaczenie użytych przez Richterów terminów (jak „astrum”), i tłumacząc, dlaczego richterowskie „tynktury” i „panacea” nie są cennymi i bezpiecznymi lekami, lecz

geben nach in allen Leibes-Beschwerden ohne Unterscheid / nicht eben so sicher zugebrauchen. Zusteuer der Wahrheit / nöthiger Ehren-Rettung auch jedemanns Nachricht und Warnung Ambts- und Gewissens halber zu Druck befördert, Wittenberg 1683. 
truciznami. Tam gdzie twierdzenia rozpowszechniane przez Richterów w sposób szczególnie rażący kłóciły się z poglądami największych autorytetów jatrochemii, członkowie Collegium cytowali odpowiednie ustępy z dzieł Paracelsusa ${ }^{91}$ lub van Helmonta ${ }^{92}$, jak również Farmakopee medyko-chymiczna Johanna Schrödera ${ }^{93}$, Klucz farmaceutyczny Friedricha Hoffmanna ${ }^{94}$ czy Chymie w formie sztuki utożona Wernera Rolfincka ${ }^{95}$. Wśród cytowanych prac znalazło się też Novum Lumen Chymicum Michała Sędziwoja oraz traktat o pulsie Józefa Strusia (egzemplarz pierwszego wydania znajdował się w bibliotece Gimnazjum).

Nie wiadomo, jak zakończył się spór szczecińskiego Collegium Medicum $\mathrm{z}$ braćmi Richterami - dokumenty na ten temat, o ile istniały, przepadły wraz z archiwum miejskim Szczecina, zaginionym pod koniec II wojny światowej. Co jednak intrygujące, w odpowiedzi na zarzuty postawione w Zmorze ${ }^{96}$ Johann Richter ani słowem nie odniósł się do kwestii składu specyfików, które wraz z bratem reklamował i sprzedawał. Skupił się wyłącznie na sprawie uprawnień do produkcji i dystrybucji leków. Oznajmił mianowicie, że i on, i Gottfried posiadają dyplomy i tytuły doktorów medycyny, jednak dokumentów poświadczających te twierdzenia nie przedłożył Collegium ani też nie przedrukował w replice „z braku miejsca i wysokich kosztów druku” (co jednak nie powstrzymało go przed zamieszczeniem w omawia-

${ }^{91}$ Ze stylu odwołań (np. „Paracelsus Oper. suor. Tom. I C. Xij. p.m. 302”) można przypuszczać, że Zander i współpracownicy dysponowali edycją dzieł wszystkich tego autora (Philip. Theoph. Paracelsi Bombasti ab Hohenheim [...] Opera omnia medicochemico-chirurgica, tribus voluminis comprehensa [...]), być może wydaniem genewskim z 1658 r. jako stosunkowo łatwo dostępnym.

${ }_{92}$ J.B. van Helmont, Ortus Medicinae. Id est, Initia physicae inaudita. Progressus medicinae novus in morborum ultionem, ad vitam longam, Amstelodami 1652 . W Zmorze znajdują się cytaty z zamieszczonego w tym wydawnictwie traktatu Potestas medicaminum (s. 376-387).

${ }^{93}$ Wydanie tego dzieła z 1677 r. jeszcze pod koniec XIX w. znajdowało się w zbiorach biblioteki Gimnazjum Mariackiego. APS, Gimnazjum Mariackie, sygn. 1360, s. 227.

${ }_{94}$ F. Hoffmann, Clavis pharmaceutica Schröderiana, seu Animadversiones cum Annotationibus in Pharmacopoeiam Schröderianam; Baconianis, Cartesianis \& Helmontianis Principiis illustrate [...], Halae Saxonum 1675. 1662 .

${ }_{95}$ G. Rolfincius, Chymia in artis formam redacta, sex libris comprehensa, Jenae

${ }^{96}$ J. Richter, Apologia contra Larvam Impiam \& Calumniosissimam â Johann Zandern / Johann Georg Lieben / Daniel Gottfried Klugen / \& Johann Gerdes, Stetini, degentibus Iniqve \& malitiose quidem Richtero affictam Verum in ipsis dictis Autoribus repertam, Oder Gründliche Wiederlegung der garstigen Schand-Larve, welche sie wieder etliche meines Vaters köstliche Chimische Medicamenta [...] zusammen geschmieret, Zittau 1683. 
nej publikacji kilkunastostronicowego katalogu zachwalającego całą gamę specyfików chymicznych produkcji własnego ojca ${ }^{97}$ ).

Podsumujmy. Georg Kirstenius był wobec jatrochemii nastawiony nieprzychylnie. Jego zdaniem filozoficzne podstawy tego prądu roiły się od rażących błędów logicznych, przejęty z alchemii mistyczny, pełen neologizmów język był pustosłowiem świadczącym o ignorancji (i arogancji) jego użytkowników, a jatrochemiczny algorytm terapeutyczny (rozpoczynanie kuracji od najgwałtowniej działających leków chymicznych, by ewentualnie później dołączyć do nich środki pochodzenia roślinnego i postępowanie dietetyczne), przeczył zdrowemu rozsądkowi. Ostatecznie jatrochemię dyskwalifikowały w jego oczach pompatyczne deklaracje cudownej skuteczności kuracji chymicznych (zwłaszcza z użyciem „złota pitnego”) oraz równych boskim kompetencji (np. zdolności tworzenia życia / duszy), mających być udziałem odpowiednio głęboko wtajemniczonych chymików. Tę ocenę Kirstenius wystawiał na podstawie stricte teoretycznej krytyki twierdzeń głoszonych przez zwolenników jatrochemii w ujęciu paracelsjańskim. Johann Zander z kolei ze znawstwem posługiwał się językiem i warsztatem chymicznym, chociaż nie zgadzał się z podstawowymi założeniami paracelsjańskiej filozofii przyrody (jak np. tria principia). Jego sprzeciw budziły przede wszystkim próby nadużywania jatrochemii przez osoby nieuprawnione do prowadzenia praktyki lekarskiej lub aptekarskiej.

\title{
Summary \\ Georg Kirstenius (1613-1660) and Johann Zander (1624-1695), professors of medicine at Szczecin's Paedagogium/Gymnasium Carolinum, on iatrochemistry
}

\begin{abstract}
This paper discusses the attitudes towards chymistry and iatrochemistry presented by Szczecin's first professors of medicine, Georg Kirstenius and Johann Zander. They had similar academic backgrounds, but their opinions on chymistry differed. Kirstenius was appalled by chymistry's dialect, with its baffling neologisms and idioms. He rejected both theoretical background and therapeutic methods of iatrochemistry, and showed no interest in performing chymical experiments. However, he was well acquainted with works by Hoffman, Billich, and Sennert. Zander was
\end{abstract}

${ }_{97}$ Tamże, strony nienumerowane (Kurzer Bericht vom Gebrauch etlicher sonderbahren köstlichen Medicamenten / welche mein Vater / Herr Christoph Richter / Medicinae Doctor [...] durch gottes Seegen und fleißiges nachforschen erfunden und in seiner [...] Praxi, an unzehlich viel Patienten / sehr nützlich und ersprüßlich befunden hat). 
a proficient user of chymical language, and seems to have had substantial practical experience in experimental chymistry. This enabled him to expose a local impostor who advertised antimony- and mercury-based preparations as panacea made of gold. Zander, however, was no follower of Paracelsian natural philosophy; particularly, he did not accept the concept of tria prima.

Keywords: chymistry; 17th century; iatrochemistry; aurum potabile 